\section{Deflection and Flexural Strength Effects on the Roughness of Aesthetic-Coated Orthodontic Wires}

Cibele Gonçalves de Albuquerque, Américo Bortolazzo Correr², Giovana Cherubini Venezian ${ }^{1}$, Milton Santamaria Jr. ${ }^{1}$, Carlos Alberto Tubel ${ }^{1}$, Silvia Amélia Scudeler Vedovello ${ }^{1}$

\author{
'Department of Orthodontics, \\ Fundação Hermínio Ometto- \\ UNIARARAS, Araras, SP, Brazil \\ ${ }^{2}$ Department of Restorative \\ Dentistry, Dental Materials \\ Division, Piracicaba Dental School, \\ UNICAMP - Universidade Estadual \\ de Campinas, Piracicaba, SP, Brazil
}

Correspondence: Prof. Sílvia Amélia S. Vedovello, Avenida Maximiliano Baruto 500, 13607-339 Araras, SP, Brasil. Tel: +55-19-3543-1423.

E-mail: silviavedovello@gmail.com

\begin{abstract}
The aim was to evaluate the flexural strength and the effects of deflection on the surface roughness of esthetic orthodontic wires. The sample consisted of 70 archwire 0.014 -inch: polytetrafluorethylene (PTFE)-coated Nickel-Titanium (Niti) archwires (Titanol Cosmetic-TC, Flexy Super Elastic Esthetic-FSE, esthetic Nickel Titanium Wire-ANT); epoxy resin-coated Niti archwires (Spectra-S, Niticosmetic-TEC); gold and rhodium coated Niti (Sentalloy-STC) and a control group (superelastic Niti (Nitinol-NS). The initial roughness was evaluated with a rugosimeter. After that, the wires were submitted to flexural test in an universal testing machine. Each wire was deflected up to $2 \mathrm{~mm}$ at a speed of $1 \mathrm{~mm} / \mathrm{min}$. After flexural test, the roughness of the wires was evaluted on the same surface as that used for the initial evaluation. The data of roughness and flexural strength were analyzed by one-way ANOVA and Tukey's test $(\alpha=0.05)$. Student t-test compared roughness before and after deflection $(\alpha=0.05)$. The roughness of $S$ and ANT (epoxy resin and PTFE-coated wires, respectively), before and after deflection, was significantly higher than the other groups $(p<0.05)$. Wire deflection significantly increased the roughness of the wires $S$ and STC $(p<0.05)$. The flexural strength of groups FSE and NS (PTFE and uncoated) was higher compared with that of the other groups $(p<0.05)$. We concluded that the roughness and flexural strength of the orthodontic wires does not depend on the type of the esthetic coating, but it is influenced by the method of application of this coating. The deflection can increase the roughness of the esthetic orthodontic wires.
\end{abstract}

Key Words: wires, orthodontic corrective, topography

\section{Introduction}

The concern of the patients about esthetics is not restricted to correction of the malocclusion, but also with the appearance of the orthodontic appliance. At present, many patients seek the orthodontic treatment by the availability of the esthetic materials. Manufacturing methods have been developed to improve the esthetic quality of arch wires to make them less perceptible. One of the methods is to cover the surface of the metal arch wire with polytetrafluoroethylene (PTFE) or with epoxy resin with a color similar to that of teeth. Another method is to cover the orthodontic wires with gold and rhodium, denominated white metals (1).

In addition to esthetic appearance, the development of esthetic orthodontic archwires aim to attain mechanical properties similar to the metallic wires (1). The orthodontic wires must be capable of withstanding mechanical, thermal and chemical stresses, because they are exposed to the oral cavity environment. Surface roughness is an important property of the orthodontic arch wire (2), since they determine the contact area of the wires with the tissues and other orthodontic appliance accessories. Problems have been related to esthetic archwires during clinical use such as color change, cracks in the esthetic coating leading exposition of the subjacent metal, causing a negative visual impact and jeopardizing the sliding mechanics (3), since archwires with rougher surfaces generate more friction (4).

Surface roughness determines the esthetics and corrosion behavior of dental products. As a result, the duration of treatment may be extended if there is no wire sliding through the bracket. Other consequences, such as more susceptibility to plaque accumulation (5), ions release in the oral cavity (6), and increased corrosion rate (7) have also caused problems in orthodontic treatment and to health of the patients. In general, it is reported that esthetic orthodontic wires do not have adequate properties for use in Orthodontics (8).

The forces released of orthodontic wires follow a diagram represented by a load/deflection graph, which records the amount of force accumulated in each millimeter of deformation (9). Due to the esthetic wire coating, the caliber of the NiTi wire inside the coatings diminished, and this alteration appears to be the variable responsible for the greatest alterations in the mechanical properties of the coated wires (10).

In some cases, large deflections are need to align the 
teeth, which may cause the fracture of the aesthetic coating of the archwires. In addition, the level of force to tooth movement may be insufficient whether the elastic modulus of the wire and the extension of deflection are low (11).

There are few studies about that evaluated the mechanical properties of esthetic wires as well as the influence of load-deflection on roughness of the esthetic wires $(12,13)$. Therefore, the aim of this study was to evaluate the flexural strength and roughness before and after the deflection of esthetic-coated NiTi orthodontic wires with different types of coatings (PTFE, epoxy resin and gold/rhodium). The hypotheses tested were: (I) there would be differences among the roughness and flexural strength of orthodontic archwires (II) the deflection would increase the roughness of the orthodontic archwires.

\section{Material and Methods}

The sample consisted of 70 nickel-titanium wire segments $(n=10)$, with a circular cross-section of 0.014inch, except for the brands Spectra and Sentalloy-Titanol Cosmetic. Athough their manufacturer informed that these wires had a 0.014-inch cross-section, measurement showed an actual value of 0.013 -inch. The type of esthetic coating and caliber of all wires are listened on Table 1.

Two straightened sections (24 $\mathrm{mm}$ in length) of each archwire were used for tests. A metal block was constructed to positioning of the wires during all the tests. On this block, edgewise metallic brackets for maxillary central incisors (Morelli, Sorocaba, SP, Brazil) were fixed with cyanoacrylate, with an interbracket distance of $12 \mathrm{~mm}$, the same used in the flexural strength test. Each test specimen was carefully placed on the brackets coupled with elastomeric modules (Morelli) (Fig. 1A).

A surface rugosimeter (Surfcorder model SE1700, Kosaka Corp., Tokyo, Japan) was used with a 5 - $\mu$ m diameter diamond stylus at a constant speed of $0.5 \mathrm{~mm} / \mathrm{s}$. The cutoff value was $0.25 \mathrm{~mm}$ and the measuring length $2.5 \mathrm{~mm}$. The wire was aligned to the needle of the rugosimeter (Fig. 1B). The surface roughness $(\mathrm{Ra}, \mathrm{mm})$ for each orthodontic wire was the average of the three readings.

After "as received" roughness evaluation, the specimens were submitted to the three point bending test. The wires were placed on the metal brackets fixed on the metal block without the use of elastomeric modules (Fig. 1C). The surface of wire (buccal surface) evaluated on the roughness test was positioned on the opposite side to the point of force application so that the chisel of the Instron would not alter the roughness of the wires.

The metal block was attached to the universal test machine (Instron, model 4411, Buckinghamshire, England).

Table 1. Description of the groups, type of the esthetic coating and caliber (in inches) of the orthodontic archwires

\begin{tabular}{lcccc}
\hline Group & Esthetic coating & Manufacturer & Brand Name & Wire Section (inch) \\
\hline TC & PTFE & Forestadent & Titanol cosmetic & 0.014 \\
FSE & PTFE & Orthometric & Flexy Super Elastic Esthetic & 0.014 \\
ANT & PTFE & TP Orthodontics & Aesthetic Nickel Titanium Wire & 0.014 \\
S & Epoxy Resin & GAC & Spectra & 0.013 \\
TEC & Epoxy Resin & Tecnident & Niti Cosmético & 0.014 \\
STC & Gold/ Rhodium & GAC & Sentalloy-Titanol Cosmetic & 0.013 \\
NS & None & 3M Unitek & Nitinol SuperElastico & 0.014 \\
\hline
\end{tabular}

The caliber of the wires was evaluated with a digital caliper (Mitutoyo MTI, Tokyo, Japan). Differences were found between the diameter of wires Spectra and Sentalloy-Titanol Cosmetic informed by manufacturer and that obtained with the caliper.
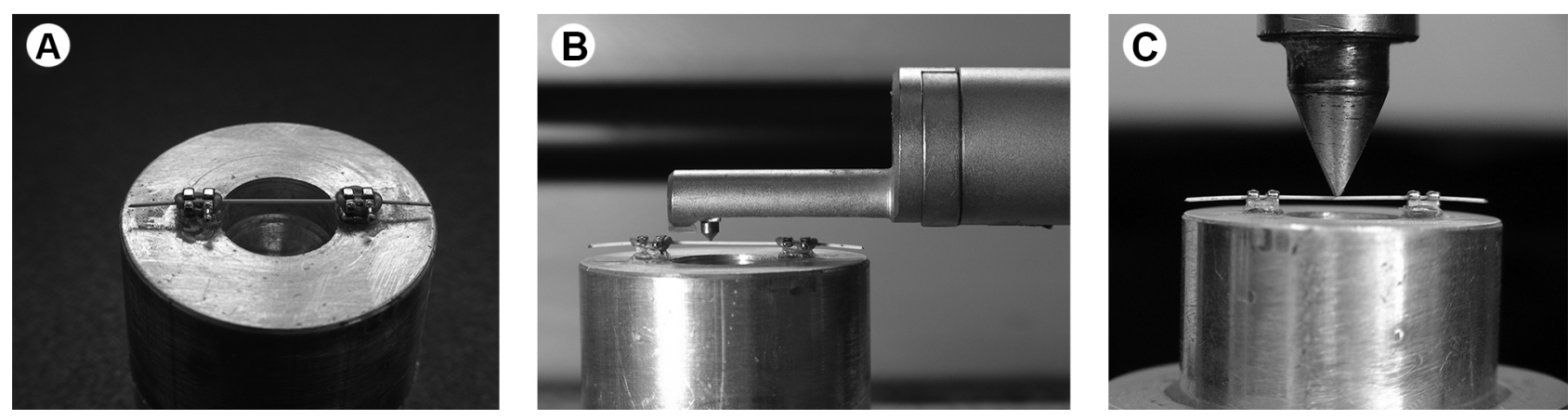

Figure 1. Representative figures of the methodologies used in the study. A: Wire segment placed on the brackets coupled with elastomeric modules. B: Diamond positioned on the wire for roughness measurement. C: Chisel positioned on the wire segment to three-point bending test. 
Each wire was deflected up to $2 \mathrm{~mm}$ at a crosshead speed of $1 \mathrm{~mm} /$ minute, with a $50 \mathrm{~N}$ load cell. The universal test machine was connected to a computer and the flexural strength results obtained by the software Bluehill 2.0 Materials Testing Software (Instron, Norwood, MA 020622643, U.S.A.). The thickness of wires was measured with a digital caliper and different thickness of the wires was found. The variation in wire caliber was considered before the test began.

After the three point bending test, the final roughness evaluation was made on the same surface of the wires following the protocol previously described.

For statistical analysis it was used the software SigmaStat (SigmaStat for Windows version 3.5.0.54, Systat Software Inc.). To test the roughness method reproducibility, 10 archwire were reexamined four weeks after initial examination. Paired t-test was used to comparison and the results showed no statistical significance between groups $(p=0.73)$. The Kolmogorv-Smirnov test was applied to evaluate the normality of data. The results had not normal distribution, indicating the use of the Kruskal-Wallis test.

Table 2. Roughness (Ra, $\mu \mathrm{m})$ means and standard deviation (SD) of the "as received" and post-deflection esthetic wires

\begin{tabular}{|c|c|c|c|c|c|c|c|c|}
\hline \multirow{3}{*}{ Esthetic coating } & \multirow{3}{*}{ Group } & \multicolumn{6}{|c|}{ Roughness $(\mu \mathrm{m})$} & \multirow{3}{*}{$\begin{array}{c}\mathrm{t} \text {-test } \\
\mathrm{p} \text { value }\end{array}$} \\
\hline & & \multicolumn{3}{|c|}{ As-received } & \multicolumn{3}{|c|}{ After Deflection } & \\
\hline & & Median & SD & $5 \%$ & Median & SD & $5 \%$ & \\
\hline PTFE & $\mathrm{TC}$ & 0.945 & 0.222 & $\mathrm{ABC}$ & 1.393 & 0.352 & $\mathrm{AB}$ & 0.006 \\
\hline PTFE & FSE & 0.366 & 0.114 & CD & 0.499 & 0.538 & $\mathrm{BC}$ & 0.064 \\
\hline PTFE & ANT & 1.396 & 1.477 & A & 1.961 & 2.037 & A & 0.455 \\
\hline Epoxy resin & S & 2.164 & 1.107 & $\mathrm{AB}$ & 3.330 & 1.023 & A & 0.004 \\
\hline Epoxy resin & TEC & 0.200 & 0.102 & D & 0.294 & 0.164 & $\mathrm{C}$ & 0.001 \\
\hline Gold and Rhodium & STC & 1.038 & 0.177 & $\mathrm{AB}$ & 1.627 & 0.405 & $\mathrm{AB}$ & 0.003 \\
\hline none & NS & 0.413 & 0.199 & $\mathrm{BCD}$ & 0.570 & 0.295 & $\mathrm{BC}$ & 0.262 \\
\hline
\end{tabular}

Different letters in the column indicate statistical significant difference by Tukey's test $(\mathrm{p}<0.05)$. Results of t-test used to compare the roughness before and after deflection, for each archwire.

Table 3. Means and standard deviation of flexural strength (MPa)

\begin{tabular}{lcccl}
\hline Esthetic coating & Group & Flexural strength $(\mathrm{MPa})$ & Standard Deviation & $5 \%$ \\
\hline PTFE & TC & 529.0 & 5.7 & DE \\
PTFE & FSE & 701.4 & 59.1 & B \\
PTFE & ANT & 633.2 & 13.4 & $\mathrm{C}$ \\
Epoxy resin & S & 494.2 & 15.8 & E \\
Epoxy resin & TEC & 554.8 & 46.3 & D \\
Gold and Rhodium & STC & 627.3 & 39.4 & $\mathrm{C}$ \\
None & NS & 870.9 & 17.8 & $\mathrm{~A}$ \\
\hline
\end{tabular}

Different letters indicate statistical difference by Tukey's test $(\mathrm{p}<0.05)$.
The paired t-test was used to comparison (for each group) of the roughness before and after deflection. The data of flexural strength was submitted to one-way analysis of variance (ANOVA) followed by the Tukey's test. The level of significance for all analyses was set to $\alpha=0.05$.

\section{Results}

\section{Roughness}

ANOVA showed significant differences among wires before $(p<0.001)$ and after deflection $(p<0.001)$. The highest "as-received" roughness (Table 2) was presented by $\mathrm{S}$ and ANT (epoxy resin and PTFE esthetic coatings, respectively), significant different from the other groups $(p<0.05)$, except for STC (Rhodium/Gold).

After deflection, the highest roughness was presented by wire $S$, significantly different from the other groups, except for ANT. The lowest roughness was found by TEC (epoxy resin), significantly different from ANT, $S$ and STC (PTFE, epoxy resin and gold and rhodium coatings, respectively).

The paired t-test (comparison between "as-received" and post-deflection roughness) showed a significantly increased roughness for TC, S, TEC and STC (epoxy resin and Gold/Rhodium coatings) after deflection, while no significant differences were found for the other orthodontic wires $(p<0.01)$.

\section{Flexural strength ( $\mathrm{MPa}$ )}

The flexural strength (Table 3) of Group S (epoxy resin) was significantly lower than that of the other groups $(p<0.05)$, except for TC (PTFE). The flexural strength of NS (control group without coating) was significantly higher compared to the other groups $(p<0.05)$.

\section{Discussion}

The use of esthetic appliances during orthodontic treatment has been increased. Thus, there is a great concern about the behavior of these materials during orthodontic mechanics. In this study it was evaluated the roughness 
of esthetic orthodontic archwires before and after load deflection. The 0.014-inch wire was chosen because, in general, it is used at the beginning of alignment and leveling, and because it undergoes large deflections required at this stage. Therefore, significant alterations may lead to instability of the esthetic lining, or in the union of the polymeric wire fibers, increasing the friction with orthodontic brackets. The quantity of tooth movement during orthodontic treatment depends on the force on the two surfaces, as well as roughness and nature of the materials involved (14).

Problems associated with the loss of coating during clinical use have been related in the literature, and for this reason, simulation of clinical use was performed by means of the deflection test, in order to observe these changes $(15,16)$. In this study, 70 orthodontic Niti wires coated with PTFE, epoxy resin, gold/rhodium metals and a group without coating were evaluated.

The presence of coating on orthodontic wire would initially reduce its roughness by the decrease of irregularities on its surface, and it would function as a type of lubricant, which would facilitate the wire sliding in the bracket (17). However, a previous study has verified that some esthetic coatings increased the roughness, and other coatings reduced the roughness (12). In this study, it was verified that before deflection, the roughness of Groups $S$ and ANT (coated with resin epoxy and PTFE, respectively), was significantly higher than that of the other groups evaluated $(p<0.05)$, except for STC (coated with gold/ rhodium). Thus the first hypothesis was accepted. Group $S$ probably presented higher initial roughness because greater porosity was shown in the resin epoxy coating, as was also verified in a previous study (13). This porosity depends on the coating (type of material) and/or method of application of this coating on the NiTi wire.

Previous studies have suggested that the PTFE esthetic coating has the potential to reduce the resistance to sliding of orthodontic archwires (18). In this study, it was verified that the ANT wire, which has a PTFE esthetic coating on the vestibular surface, presented a higher roughness value than the other wires. One of the factors responsible for the higher roughness value shown for this wire is that there are many irregularities in the area of transition between the esthetic coating and that without coating. During the roughness evaluation, this region may have been analyzed, which led to the high roughness values for this wire. In addition, the method of application of the esthetic coating on the wire leads to surface irregularities, thereby increasing the roughness (4).

Group S (coated with resin epoxy) presented the highest roughness value after deflection $(p<0.05)$. As previously related, the orthodontic wires with resin epoxy coating observed by electronic microscopy presented surface porosities (13). During deflection, these porosities may function as locations of stress concentration, which lead to fracture of the esthetic coating. Other studies have shown that after use in vivo the roughness of wires with coatings increases (15). However, further clinical studies are necessary in order to know whether the duration of orthodontic treatment would be longer due to this increase in roughness, taking into consideration the biologic complexity involved in tooth movement.

The roughness of S and STC wires increased significantly after deflection. Thus the second hypothesis of the study was accepted. As previously reported, the increase in roughness of wire $S$ may be due to fracture or partial loss of the esthetic coating. In one research, ten archwires were used in vivo, for a period between 4 and 6 weeks and these were examined before and after use. Under the microscope, the coated archwires discolored, delaminated and their surface roughness increased after use. It was concluded that coated archwires have a low esthetic value, with $25 \%$ of the coating being lost after 33 days (15). The variation between initial and post-deflection roughness of the Group ANT was not significant, as this group presented high initial roughness values.

The STC wire is coated with gold and rhodium, which are called white metals, with the purpose of increasing shine. Authors have studied the effect of two nickeltitanium esthetic wires, Woowa (Dany Harvest) and Bioforce (Dentsply GAC) of $0.016 \times 0.022$-inch compared with the same brands without coatings. The surfaces of both coated wires were shown to be rougher in comparison with the wires without coating (19). In another study, a microscopy evaluation of orthodontic wires with and without esthetic coating verified increased roughness for the NiTi wires with implantation of Rhodium ions (12).

It is suggested that the ion implantation procedure should diminish the roughness of the material and increase sliding. It has been verified that NiTi wires submitted to deflection stress presented corrosion in artificial saliva. This occurs in the areas of wire under tension and not in the areas of passive wire configuration (20). The higher roughness values of STC wire after deflection may be due to surface corrosion. The purpose of ion implantation is to increase the hardness, reduce flexibility and improve the surface finish (21). However, in order to obtain maximum frictional reduction, this ion implantation must be performed periodically (22).

Nickel-Titanium (NiTi) has been used in Orthodontics due to the unique properties, such as the shape memory effect and superelasticity (23). Alteration in the deflection of wires with coating may change the properties of these wires. Deflection is the amount of force accumulated per 
millimeter of deformation. In this research the flexural strength of Group S (resin epoxy) was significantly lower than it was in the other groups, except for TC (PTFE). Moreover, the control group presented higher flexural strength compared to the other wires. At the beginning of the research the caliber of the orthodontic wires was verified, and it was approximately 0.014 inches. Coating increases the total caliber of the wire by an average of 0.3 $\mathrm{mm}$. To maintain the caliber of the wires at 0.014-inches, manufacturers have to reduce the caliber of the internal part of the wires; that is to say, diminish the caliber of the NiTi core. In a previous study, it was verified that some coated wires presented higher flexural strength than the non-coated wires (24). This probably occurs due to the reduction of the caliber of the NiTi wires to accommodate the esthetic coating without increasing on the final caliber of the wires. In a study comparing wires with and without coating, it was concluded that the groups with a metal core of the same thickness presented similar properties. The group with the smaller caliber of the metal core, which was reduced in order to apply the coating, presented reduced mechanical properties (10). Another factor to consider is peeling in the areas submitted to deflection, further diminishing the caliber of the wire. One study compared wires coated with resin epoxy and metal wires, and found that the esthetic wires generate lower flexural strength (15).

Due to the greater roughness of some esthetic wires and the differences in flexural strength, the choice of materials with less change in surface morphology after deflection is important in order to optimize treatment. Esthetic wires may be used clinically, however, the cases to be treated with esthetic wires must be selected with attention, to ensure that their evolution and esthetics are not compromised. The wire of choice for esthetic orthodontic treatment must present a lower level of roughness to diminish friction and allow sliding between the wire/bracket. The lower load-deflection is important at the stage of alignment and leveling. Wires with large degrees of deflection will release light and continuous forces during deactivation of the wire, which minimize permanent tissue damage during tooth movement. Therefore, when selecting an esthetic wire, one must take into consideration the surface roughness of the wire in order to optimize the treatment (25). We concluded that the roughness and flexural strength of the orthodontic wires do not depend on the type of the esthetic coating, but it is influeced by the method of application of this coating. Esthetic coated archwires presented lower flexural strength compared to non-coated archwires. The deflection can increase the roughness of some esthetic orthodontic wires. Further studies that evaluate other factors involved on the loss of the esthetic coating during use are needed.

\section{Resumo}

0 objetivo foi avaliar a resistência a flexão e os efeitos da deflexão na rugosidade de superfície de fios ortodônticos estéticos. A amostra foi composta por 70 segmentos de fios NiTi calibre 0,014 polegadas: revestidos por politetrafluoretileno (PTFE) (Titanol Cosmetic-TC, Flexy Super Elastic Esthetic-FSE, Aesthetic Nickel Titanium Wire-ANT); revestidos por resina epoxídica (Spectra-S, Niticosmetic-TEC); revestidos por ouro e ródio (Sentalloy-STC); e grupo controle sem revestimento (Nitinol-NS). A rugosidade inicial foi avaliada em perfilômetro. Em seguida, os fios foram submetidos ao teste de resistência a flexão 3 pontos em máquina de ensaio universal. Cada fio foi defletido até $2 \mathrm{~mm}$ com velocidade de $1 \mathrm{~mm} / \mathrm{min}$. Após o ensaio de resistência a flexão, a rugosidade dos fios foi verificada na mesma superfície avaliada inicialmente. Os resultados rugosidade e resistência a flexão foram analisados por análise de variância 1 fator e teste de Tukey $(\alpha=0,05)$. Teste t de Student foi utilizado para comparação da rugosidade antes e após deflexão $(\alpha=0.05)$. A rugosidade de $\mathrm{S}$ e ANT (revestimentos resina epoxídica e PTFE, respectivamente), antes e após a deflexão, foi significativamente maior que dos demais grupos $(p<0,05)$. A deflexão aumentou significativamente a rugosidade dos fios S e STC $(p<0,05)$. A resistência a flexão de FSE e NS (teflon e sem recobrimento, respectivamente) foi maior comparada aos demais grupos $(p<0,05)$. Conclui-se que a rugosidade e resistência a flexão não dependem do tipo de revestimento estético, mas é influenciada pelo modo de aplicação deste revestimento. A deflexão pode aumentar a rugosidade de alguns fios estéticos.

\section{References}

1. Imai $T$, Yamagata $S$, Watari $F$, Kobayashi M, Nagayama K, Toyoizumi $H$ et al. Temperature-dependence of the mechanical properties of FRP orthodontic wire. Dent Mater J 1999;18:167-175.

2. Huang $\mathrm{HH}$. Variation in surface topography of different NiTi orthodontic archwires in various commercial fluoride-containing environments. Dent Mater 2007;23:24-33.

3. Lim KF, Lew KK, Toh SL. Bending stiffness of two aesthetic orthodontic archwires: an in vitro comparative study. Clin Mater 1994;16:63-71.

4. Husmann $P$, Bourauel $C$, Wessinger $M$, Jager $A$. The frictional behavior of coated guiding archwires. J Orofac Orthop 2002;63:199-211.

5. Taha $\mathrm{M}$, El-Fallal $\mathrm{A}$, Degla $\mathrm{H}$. In vitro and in vivo biofilm adhesion to esthetic coated arch wires and its correlation with surface roughness. Angle Orthod 2015;

6. Santos AA, Pithon MM, Carlo FG, Carlo HL, de Lima BA, Dos Passos TA et al. Effect of time and $\mathrm{pH}$ on physical-chemical properties of orthodontic brackets and wires. Angle Orthod 2015;85:298-304.

7. Katic V, Mandic V, Jezek D, Barsic G, Spalj S. Influence of various fluoride agents on working properties and surface characteristics of uncoated, rhodium coated and nitrified nickel-titanium orthodontic wires. Acta Odontol Scand 2015;73:241-249.

8. Kusy RP. A review of contemporary archwires: their properties and characteristics. Angle Orthod 1997;67:197-207.

9. Nucera R, Gatto E, Borsellino C, Aceto P, Fabiano F, Matarese $G$ et al. Influence of bracket-slot design on the forces released by superelastic nickel-titanium alignment wires in different deflection configurations. Angle Orthod 2014;84:541-547.

10. Silva DL, Mattos CT, Sant' Anna EF, Ruellas AC, Elias CN. Cross-section dimensions and mechanical properties of esthetic orthodontic coated archwires. Am J Orthod Dentofacial Orthop 2013;143:S85-91.

11. Burstone CJ, Qin B, Morton JY. Chinese NiTi wire--a new orthodontic alloy. Am J Orthod 1985;87:445-452.

12. D'Anto V, Rongo R, Ametrano G, Spagnuolo G, Manzo P, Martina R et al. Evaluation of surface roughness of orthodontic wires by means of atomic force microscopy. Angle Orthod 2012;82:922-928.

13. Kim IH, Park HS, Kim YK, Kim KH, Kwon TY. Comparative short-term in vitro analysis of mutans streptococci adhesion on esthetic, nickeltitanium, and stainless-steel arch wires. Angle Orthod 2014;84:680686.

14. Hain M, Dhopatkar $A$, Rock $P$. The effect of ligation method on friction 
in sliding mechanics. Am J Orthod Dentofacial Orthop 2003;123:416422.

15. Elayyan F, Silikas N, Bearn D. Ex vivo surface and mechanical properties of coated orthodontic archwires. Eur J Orthod 2008;30:661-667.

16. Juvvadi SR, Kailasam V, Padmanabhan S, Chitharanjan AB. Physical, mechanical, and flexural properties of 3 orthodontic wires: an in-vitro study. Am J Orthod Dentofacial Orthop 2010;138:623-630.

17. Clocheret $K$, Willems $G$, Carels $C$, Celis JP. Dynamic frictional behaviour of orthodontic archwires and brackets. Eur J Orthod 2004;26:163-170.

18. Farronato G, Maijer R, Caria MP, Esposito L, Alberzoni D, Cacciatore G. The effect of Teflon coating on the resistance to sliding of orthodontic archwires. Eur J Orthod 2012;34:410-417.

19. lijima M, Muguruma T, Brantley W, Choe HC, Nakagaki S, Alapati SB et al. Effect of coating on properties of esthetic orthodontic nickeltitanium wires. Angle Orthod 2012;82:319-325.

20. Liu IH, Lee TM, Chang CY, Liu CK. Effect of load deflection on corrosion behavior of NiTi wire. J Dent Res 2007;86:539-543.
21. Burstone CJ, Farzin-Nia F. Production of low-friction and colored TMA by ion implantation. J Clin Orthod 1995;29:453-461.

22. Doshi UH, Bhad-Patil WA. Static frictional force and surface roughness of various bracket and wire combinations. Am J Orthod Dentofacial Orthop 2011;139:74-79.

23. Kobayashi S, Ohgoe Y, Ozeki K, Hirakuri K, Aoki H. Dissolution effect and cytotoxicity of diamond-like carbon coatings on orthodontic archwires. J Mater Sci Mater Med 2007;18:2263-2268.

24. Kaphoor AA, Sundareswaran $\mathrm{S}$. Aesthetic nickel titanium wires-how much do they deliver? Eur J Orthod 2012;34:603-609.

25. Read-Ward GE, Jones SP, Davies EH. A comparison of self-ligating and conventional orthodontic bracket systems. Br J Orthod 1997;24:309317.

Received May 12, 2016 Accepted November 1, 2016 